\title{
Biochemical and Microbiological Characterization of Prickly Pear Rejects
}

\author{
Loubna EL HAJJI, \\ Ecology and sustainable development Laboratory, Faculty \\ of Science and Technology, Sultan Moulay Slimane \\ University \\ Beni Mllal, Morocco
}

\begin{abstract}
The aim of this work is to study the biochemical and microbiological characterization of the prickly pear fruits abandoned in the fields after harvest in order to use it in the animal feed. This work reveal that the skin and pulp have a $\mathrm{pH}$ close to neutral $(6.83$ for the skin and 6.41 for the pulp), they are very rich in water $(84.89 \%$ for the skin and $87.19 \%$ for the pulp), in sugars (31.19 \% DM for the skin and 42.17\% DM for the pulp) and in mineral elements $(13.7 \%$ DM for the skin and $4.46 \% \mathrm{DM}$ for the pulp). They have average values in NDF, ADF, ADL, cellulose and hemicellulose fibers which values are respectively for the skin $11.72 \%$ DM, 7.75\% DM, 1.25\% DM, 3.98\% DM, 6.5\% DM and for the pulp 8.50\% DM, 5.67\% DM, 1.45\% DM, $2.84 \%$ DM, $4.22 \%$ DM. The crude protein content is $4.84 \%$ $\mathrm{DM}$ for the skin and $10.2 \% \mathrm{DM}$ for the pulp respectively remains low in comparison with other food by-products such as oilseed meal. The fat content is very low $(0.09 \%$ DM for the skin and $0.17 \%$ DM for the pulp). As for the seeds, the results showed a low content of water $(14.6 \%)$, mineral elements $(1.99 \%$ DM), sugars (8.18 \% DM) and crude proteins (7.66\% DM), high fat contents ( $8.91 \% \mathrm{DM}$ ) and NDF, ADF, ADL, cellulose and hemicellulose fibers wish are respectively $\mathbf{7 8 . 1 8 \%}$ DM, 62.99\% DM, 42.94\% DM, $15.19 \%$ DM, $20.05 \%$ DM. On the microbiological side, the results showed a significant load of microorganisms in this case molds and lactic bacteria which can be exploited in the recovery of these residues. The comparison between the three fractions of the cactus fruit showed that the seed is the richest in dry matter, fat and fiber, while the pulp is the richest in sugars, the skin when it is the richest in calcium.
\end{abstract}

Keywords:- Cactus Fruit, Pulp, Skin, Seeds, Characterization, Biochemical, Chemical, Microbiological.

\section{INTRODUCTION}

All over the world, animal production is increasing year after year in order to meet the growing need for animal food products. However, in Morocco as in other southern countries, food resources are one of the factors limiting animal production. Faced with this pressing shortage of animal feed, the use of food residues offers attractive solutions. In addition, it could satisfy the national need for environmental protection and to encourage autonomous

\author{
Souad SALMAOUI * \\ Ecology and sustainable development Laboratory, Faculty \\ of Science and Technology, Sultan Moulay Slimane \\ University \\ Beni Mllal, Morocco
}

depollution. Indeed, several processes using physical, chemical or biological treatments have been proposed.

In this context, we are interested in a food residue available in appreciable quantities in our country, the peels of prickly pears. Indeed, the growth in the consumption of prickly pear fruits and the development of industrial cultivation generates significant quantities of solid waste in terms of rejects.

This rejects poses serious pollution problems. Their valorization proves to be important from both ecological and economic interest.

The extraction of pectins from prickly pear bark is still limited due to the very low yields obtained during the investigations undertaken in this context by Forni et al. (1994).

On the other hand, the cactus (Opuntia ficus-indica) is a seasonal product, producing large quantities of fruit in a short period. The period of fruit maturity is relatively short especially when the summer period is accompanied by high heat. As a result, between 30 and $50 \%$ of these fruits ripen quickly and become unfit for human consumption (AitOubahou and Bartali, 2015) (M. Bendaou, 2013). Therefore, it is necessary to look for new ways of valorizing these residues, such as using them in animal feed.

For these reasons, we have exanimate biochemical and microbiological characterization of cactus fruit (pulp, skin, seeds), with the aim to use it in animal feed.

\section{MATERIALS AND METHODS}

\section{A. Sampling \\ After harvest in the region of Beni Mellal (in the center of morocco), 12 prickly pear samples were collected at the end of the season; it concerned fruits abandoned in the field. After collection, these samples were immediately stored in cold storage $\left(-4^{\circ} \mathrm{C}\right)$.}

These samples were submitted to a series of biochemical and microbiological analyses by different methods, in order to determine their main constituents. 


\section{B. Chemical analyses}

The dry weight was determined by steaming at $105^{\circ} \mathrm{C}$ to constant weight, the mineral matter by incineration at $550^{\circ} \mathrm{C}$, the fat by continuous extraction using hexane as solvent according to the Soxhlet method. Crude protein was determined by the Kjedahl method described by APHA. (1989), fiber by the Van Soest et al. (1991). The pH was determined using a $\mathrm{pH}$ meter. $20 \mathrm{~g}$ of the sample was mixed in a blender with $50 \mathrm{ml}$ distilled water until a fluid suspension was obtained (Habibi, 2004), and the mineral elements by atomic absorption spectroscopy as the most widely used and reliable method.

\section{Microbiological analyses}

The microbiological characterization was carried out according to the culture technique in selective media. The Plat Count Agar (PCA) medium for the Total Aerobic Mesophilic Flora (FMAT), the medium with the potato extract (PDA) for the yeasts and molds, Man Rogosa and Sharpe (MRS) agar for lactic acid bacteria, Mac Conkey agar for total coliforms. The method followed is that described by Leininger. (1976). Counting occurred after 72 hours at $30^{\circ} \mathrm{C}$ pour FMAT, 5 days at $25^{\circ} \mathrm{C}$ for yeasts and molds and $72 \mathrm{~h}$ at $37^{\circ} \mathrm{C}$ for lactic acid bacteria.

\section{Statistical analyses}

All chemical analyses are presented on a DM basis (except $\mathrm{DM}$ and $\mathrm{pH}$ ), the microbial data was converted to $\log 10$ and is presented on a wet matter basis.

The data were subjected to a single criterion analysis of variance according to a general linear model (GLM) using SAS software Microsoft Windows 8.0 (SAS, 1999). The significant differences between means were determined at $\mathrm{P}<0.05$ level.

The overall structure of the biochemical variability of the three fractions of the fruit was described by the principal component analysis (PCA) using the XLSTAT software (2016).

\section{RESULTS AND DISCUSSION}

\section{A. Skin composition}

The results obtained (Table 1) show that the skin of the fruit of Opuntia ficus indica has a high water content $(84.72 \%)$ and a low dry matter value of $15.28 \%$. Therefore, it is advisable to use the cactus only as a supplement in animal feed because it can cause diarrhea due to the associated water level (Araba et al., 2009).

\begin{tabular}{|c|c|c|c|}
\hline & Range & Mean & Standard deviation \\
\hline $\mathrm{pH}$ & $6.78-6.88$ & 6,83 & 0.02 \\
\hline Humidity $\%$ & $83.25-86.50$ & 84,80 & 1.18 \\
\hline DM \% & $13.5-16.75$ & 15,20 & 1.18 \\
\hline Total Sugars (\% DM) & $28.53-33.25$ & 31.19 & 1.38 \\
\hline Reducing Sugars (\% DM) & $21.82-27.15$ & 23.63 & 1.46 \\
\hline Ashes (\% DM) & $12.59-16.05$ & 13,70 & 0.9 \\
\hline Fat $(\% \mathrm{DM})$ & $0.028-0.131$ & 0,09 & 0.028 \\
\hline Crude Protein (\% DM) & $3.5-7.88$ & 4,84 & 1.78 \\
\hline NDF (\% DM) & $9.7-15.97$ & 11.72 & 0.91 \\
\hline $\mathrm{ADF}(\% \mathrm{DM})$ & $6.21-8.6$ & 7,75 & 0.51 \\
\hline ADL (\% DM) & $0.95-1.56$ & 1,25 & 0.16 \\
\hline Hemicellulose (\% DM) & $1.91-9.02$ & 3,97 & 1.03 \\
\hline Cellulose (\% DM) & $4.93-7.45$ & 6,50 & 0.54 \\
\hline $\mathrm{Ca}(\mathrm{mg} / 100 \mathrm{~g}$ FM) & $88.32-123.83$ & 108.76 & 8.61 \\
\hline $\mathrm{K}(\mathrm{mg} / 100 \mathrm{~g}$ FM $)$ & $21.04-31.55$ & 25.97 & 2.34 \\
\hline $\mathrm{Na}(\mathrm{mg} / 100 \mathrm{~g} \mathrm{FM})$ & $0.97-1.79$ & 1.4 & 0.21 \\
\hline $\mathrm{Cu}(\mathrm{mg} / 100 \mathrm{~g}$ FM) & $0.42-0.83$ & 0.64 & 0.10 \\
\hline $\mathrm{Mg}(\mathrm{mg} / 100 \mathrm{~g} \mathrm{FM})$ & $7.26-10.99$ & 9.42 & 0.80 \\
\hline Fe (mg/100g FM) & $0.22-0.35$ & 0.29 & 0.03 \\
\hline
\end{tabular}

Table 1:- Chemical characteristics of cactus peels $(n=12)$

DM: Dry Matter, NDF: Neutral Detergent Fiber, ADF: Acid Detergent Fiber, ADL: Acid Detergent Lingnin, FM: Fresh Matter.

It also has a high content of sugars $(32.8 \%$ DM for total sugars and $27.3 \%$ DM for reducing sugars) and mineral matter $(16.7 \% \mathrm{DM})$. Its fiber content remains average, they are respectively for NDF, ADF, ADL, hemicellulose and cellulose $10.96 ; 7.63 ; 1.30 ; 3.33$ and $6.31 \% \mathrm{DM}$, with a high cellulose content which rises to $60 \%$ and low lignin content of about $10 \%$ of total fiber. However, its crude protein content is low (4.73\%DM) compared to other food byproducts such as oilseed cake (Chenost and Kayouli, 1997)
(RNED, 2000). Finally, its fat content is very low $(0.07 \%$ DM).

It appears from the results obtained that prickly pear peels are mainly constituted of water and sugars, they also contain but to a lesser extent fibers and proteins, which is in agreement with the data provided by Fadili (2000). 
In terms of mineral composition, they are richer in calcium (108.76 mg/100g FM), potassium $(25.97 \mathrm{mg} / 100 \mathrm{~g}$ FM) and magnesium (9.42 mg/100g FM).

\section{B. Pulp Composition}

The results also show that the pulp of the prickly pear fruit is rich in sugars (42.17\% DM for total sugars and 31.6. $\% \mathrm{DM}$ for reducing sugars) and also in mineral elements which are present in relatively large quantities, especially potassium, calcium and magnesium (with respective values of $95.8 \mathrm{mg} / 100 \mathrm{~g}, 12.73 \mathrm{mg} / 100 \mathrm{~g}$, and $18.60 \mathrm{mg} / 100 \mathrm{~g}$ ). Iron and copper exist in trace amounts $(1.51 \mathrm{mg} / 100 \mathrm{~g}$ for iron and $0.43 \mathrm{mg} / 100 \mathrm{~g}$ for copper), what is in agreement with the results obtained by Stintzing et al. (2001) and Piga (2004).
These results also showed that prickly pear pulp has a relatively high $\mathrm{pH}$ (around 6.41) compared to that of other fruits such as orange, lemon and apricot. However, the $\mathrm{pH}$ of the pulp is close to neutral, the measured value is in agreement with the results of the work carried out in this framework. This neutral $\mathrm{pH}$ exposes more this type of fruit to microbiological alterations.

The results show an average fiber content which is respectively for NDF, $\mathrm{ADF}, \mathrm{ADF}$, cellulose and hemicellulose $8.51 \%$ DM, 5.67\% DM, 1.45\% DM, $2.84 \%$ $\mathrm{DM}$ and $4.22 \% \mathrm{DM}$, the same for crude protein $10.21 \%$ DM.

\begin{tabular}{|c|c|c|c|}
\hline & Range & Mean & Standard deviation \\
\hline pH & $6.36-6.44$ & 6.41 & 0.013 \\
\hline Humidity \% & $85.08-90.85$ & 87.01 & 1.75 \\
\hline DM \% & $9.15-14.95$ & 12.99 & 1.75 \\
\hline Total Sugars (\% DM) & $39.43-45.29$ & 42.17 & 1.04 \\
\hline Reducing Sugars (\% DM) & $30.02-33.33$ & 31.60 & 0.04 \\
\hline Ashes (\% DM) & $2.36-6.11$ & 4.46 & 0.17 \\
\hline Fat (\% DM) & $0.077-0.25$ & 0.17 & 0.43 \\
\hline Crude Protein (\% DM) & $9.63-10.5$ & 10.21 & 0.65 \\
\hline NDF (\% DM) & $6,22-9.82$ & 8.51 & 0.74 \\
\hline ADF (\% DM) & $4.38-7.67$ & 5.67 & 0.33 \\
\hline ADL (\% DM) & $0.78-2.07$ & 1.45 & 0.88 \\
\hline Hemicellulose (\% DM) & $1.39-5.21$ & 2.84 & 0.63 \\
\hline Cellulose (\% DM) & $2.89-6.53$ & 4.22 & 1.52 \\
\hline Ka (mg/100g FM) & $9.81-15.42$ & 12.73 & 11.04 \\
\hline Na (mg/100g FM) & $78.49-122.71$ & 95.88 & 0.24 \\
\hline Cu (mg/100g FM) & $0.61-1.68$ & 1.10 & 0.06 \\
\hline Mg (mg/100g FM) & $0.30-0.56$ & 0.43 & 3.12 \\
\hline Fe (mg/100g FM) & $12.11-25.61$ & 18.60 & 0.03 \\
\hline
\end{tabular}

Table 2: Chemical characteristics of cactus pulp $(n=12)$

\section{Seed composition}

The seed of the fruit is a part rich in fat $(8.91 \% \mathrm{DM})$, which justifies its use in the extraction of oils for food, pharmaceutical, medical and cosmetic uses.

This part of the fruit also appears as a compound rich in fiber (78.18\% DM for NDF, 62.99\% DM for ADF, 42.94\% DM for ADL, $15.20 \%$ DM for cellulose and $20.05 \%$ DM for hemicellulose) When the whole peeled fruit is ingested, the large amount of insoluble fiber in the seeds (El Kossori et al., 1998) is the main source of fiber in cactus fruits, and mineral elements with high amounts of calcium, potassium, magnesium and sodium, wish are respectively $15.61 \mathrm{mg} / 100 \mathrm{~g} \mathrm{FM,} \mathrm{114.89mg/100g} \mathrm{FM,}$ $25.52 \mathrm{mg} / 100 \mathrm{~g}$ FM, $69.09 \mathrm{mg} / 100 \mathrm{~g}$ FM. Iron and copper are present in trace amounts $(0.73 \mathrm{mg} / 100 \mathrm{~g}$ FM and $1.51 \mathrm{mg} / 100 \mathrm{~g}$ FM), that is in agreement with the results of Matthäus and Özcan (2011).

\begin{tabular}{|c|c|c|c|}
\hline & Range & Mean & Standard deviation \\
\hline $\mathrm{pH}$ & $6.36-6.44$ & 6.41 & 0.013 \\
\hline Humidity \% & $85.08-90.85$ & 87.01 & 1.75 \\
\hline DM \% & $9.15-14.95$ & 12.99 & 1.75 \\
\hline Total Sugars (\% DM) & $39.43-45.29$ & 42.17 & 1.04 \\
\hline Reducing Sugars (\% DM) & $30.02-33.33$ & 31.60 & 1.04 \\
\hline Ashes (\% DM) & $2.36-6.11$ & 4.46 & 0.88 \\
\hline Fat (\% DM) & $0.077-0.25$ & 0.17 & 0.17 \\
\hline Crude Protein (\% DM) & $9.63-10.5$ & 10.21 & 0.43 \\
\hline NDF (\% DM) & $6,22-9.82$ & 8.51 & 0.65 \\
\hline ADF (\% DM) & $4.38-7.67$ & 5.67 & 0.74 \\
\hline
\end{tabular}


ISSN No:-2456-2165

\begin{tabular}{|c|c|c|c|}
\hline ADL (\% DM) & $0.78-2.07$ & 1.45 & 0.33 \\
\hline Hemicellulose (\% DM) & $1.39-5.21$ & 2.84 & 0.88 \\
\hline Cellulose (\% DM) & $2.89-6.53$ & 4.22 & 0.63 \\
\hline $\mathrm{Ca}(\mathrm{mg} / 100 \mathrm{~g} \mathrm{FM})$ & $9.81-15.42$ & 12.73 & 1.52 \\
\hline $\mathrm{K}(\mathrm{mg} / 100 \mathrm{~g} \mathrm{FM})$ & $78.49-122.71$ & 95.88 & 0.04 \\
\hline $\mathrm{Na}(\mathrm{mg} / 100 \mathrm{~g} \mathrm{FM})$ & $0.61-1.68$ & 1.10 & 0.06 \\
\hline $\mathrm{Cu}(\mathrm{mg} / 100 \mathrm{~g} \mathrm{FM})$ & $0.30-0.56$ & 0.43 & 3.12 \\
\hline $\mathrm{Mg}(\mathrm{mg} / 100 \mathrm{~g} \mathrm{FM})$ & $12.11-25.61$ & 18.60 & 0.03 \\
\hline $\mathrm{Fe}(\mathrm{mg} / 100 \mathrm{~g} \mathrm{FM})$ & $0.08-0.18$ & 1.51 & 240 \\
\hline
\end{tabular}

Table 3: Chemical characteristics of cactus seed $(n=12)$

The content of total sugars is relatively low compared to the other parts of the fruit $(8.18 \% \mathrm{DM}$ total sugars and $6.26 \% \mathrm{DM}$ reducing sugars).

The average protein content of $7.66 \%$ DM means that prickly pear seed can be a source of protein for animal consumption, which is in line with the results obtained by Tlili et al. (2011).

\section{Microbiological characterization}

Given its richness in water and sugars as well as its $\mathrm{pH}$ close to neutral (6.84), the prickly pear fruit constitutes an ideal matrix for the development of microorganisms, which is proven by the results obtained after microbiological analysis. Indeed, the results of the enumeration of the endogenous microflora of the prickly pear fruit show that it is highly loaded in microorganisms: Total aerobic mesophilic flora (37.108 CFU/g FM), yeasts $\left(74.10^{1^{4}} \mathrm{CFU} / \mathrm{g}\right.$ FM), mods (3 CFU/g), lactic acid bacteria $\left(187.10^{2} \mathrm{CFU} / \mathrm{g}\right.$ FM) and coliforms (206.106 CFU/g FM). These high levels of microorganisms can be attributed to the fact that prickly pears have not been washed beforehand.

\begin{tabular}{|c|c|c|c|}
\hline & Range & Mean & Standard deviation \\
\hline $\begin{array}{c}\text { Total aerobic mesophilic flora } \\
\text { (log 10 UFC/g FM) }\end{array}$ & $7.23-10.16$ & 8.85 & 0.81 \\
\hline Yeast (log 10 UFC/g FM) & $13.03-16.32$ & 16.15 & 1.14 \\
\hline Mold (log 10 UFC/g FM) & - & 3 & 0.55 \\
\hline $\begin{array}{c}\text { lactic acid bacteria (log 10 UFC/g } \\
\text { FM) }\end{array}$ & $2.61-4.91$ & 3.83 & 0.68 \\
\hline Coliforms (log 10 UFC/g FM) & $6.34-9.09$ & 6.95 & \\
\hline
\end{tabular}

\begin{tabular}{|c|c|}
\hline Micro-organismes (CFU $* / \mathbf{g}$ FM) & Average value \\
\hline Total aerobic mesophilic flora & $37.10^{8}$ \\
\hline Yeast & $74.10^{14}$ \\
\hline Mold & 3 \\
\hline lactic acid bacteria & $187.10^{2}$ \\
\hline Coliforms & $206.10^{6}$ \\
\hline
\end{tabular}

Table 4: Distribution of the endogenous microflora of cactus fruit CFU: Colony Forming Unit, FM: Fresh Matter

\section{E. Comparison of different fractions of the cactus fruit}

The analysis of variance shows that there is a significant difference between the three fractions of prickly pear $(\mathrm{p}<0.05)$ (Fig. 1, 3, and 5). The most abundant components in the skin and pulp of the prickly pear are sugars, they constitute more than $40 \%$ DM of the pulp and more than $30 \% \mathrm{DM}$ of the skin (fig. 1). This content may constitute a good source of energy that may explain its potential use in animal feed. In fact, a study conducted in Ethiopia showed that replacing $50 \%$ of the teff straw by cactus increased the average daily gain of lambs from 23 to $53 \mathrm{~g}$ per day (Gebremariam et al., 2006). Salem et al. (2004) reported that replacing barley with cactus in the diet of barley lambs increased the average daily gain of lambs from 108 to $119 \mathrm{~g}$ per day.
Fig. 1 shows that the skin, pulp, and seed contain significantly $(p<0.05)$ different amounts of dry matter, ashes, cruds proteins, reducing sugars and total sugars. For fat, the contents are statistically identical for the peel and the pulp, the seed being the richest.

The analysis of the main component (PCA) (fig. 2) shows that the skin is the richest in ash, the pulp is the richest in reducing and total sugars. The seed also has the highest amount of dry matter and fat. The protein content was low for all three fractions. Which is similarly founded by El Kossori et al. (1998).

This high population of yeasts and lactic acid bacteria, naturally present in prickly pear fruit, shows that prickly pear fruit are a favorable substrate for microbial growth. This could be used to apply biological treatments to these 
residues in order to stabilize them or improve their nutritional value.

The coliform load in prickly pear fruit is quite high. The biological treatment to be applied to these residues must be able to inhibit these coliforms to avoid any risk of intoxication to animals.

For fibers, the seed is the richest in NDF, ADF, ADL, hemicellulose and cellulose, as for the pulp and the skin they have almost the same composition (fig. 3 and 4). El Kossori et al.(1998) confirms that the seed is the major source of fiber in cactus fruits.

With regard to mineral elements (Fig. 5 and 6), the pulp is less rich in mineral elements compared to other fractions but it is richer in potassium and magnesium than the skin. The skin of the cactus is rich in calcium, although McConn and Nakata ( 2004) have shown that its bioavailability is low due to its presence in the form of calcium oxalate, which is not absorbed.

The seed in potassium, sodium and magnesium. Iron and copper are found in trace amounts (fig. 6).

Sawaya et al. (1983) and Matthäus \& Özcan (2011) studied the composition of cactus seeds. They reported a high content of mineral elements in sodium $(67.6 \mathrm{mg} 100 \mathrm{~g}$ 1), potassium (163.0 mg $100 \mathrm{~g}-1)$, which is in agreement with the results found and presented in fig. 5 .

The mineral quantities detected in the different prickly pear fractions could make a good mineral supplement for animals.

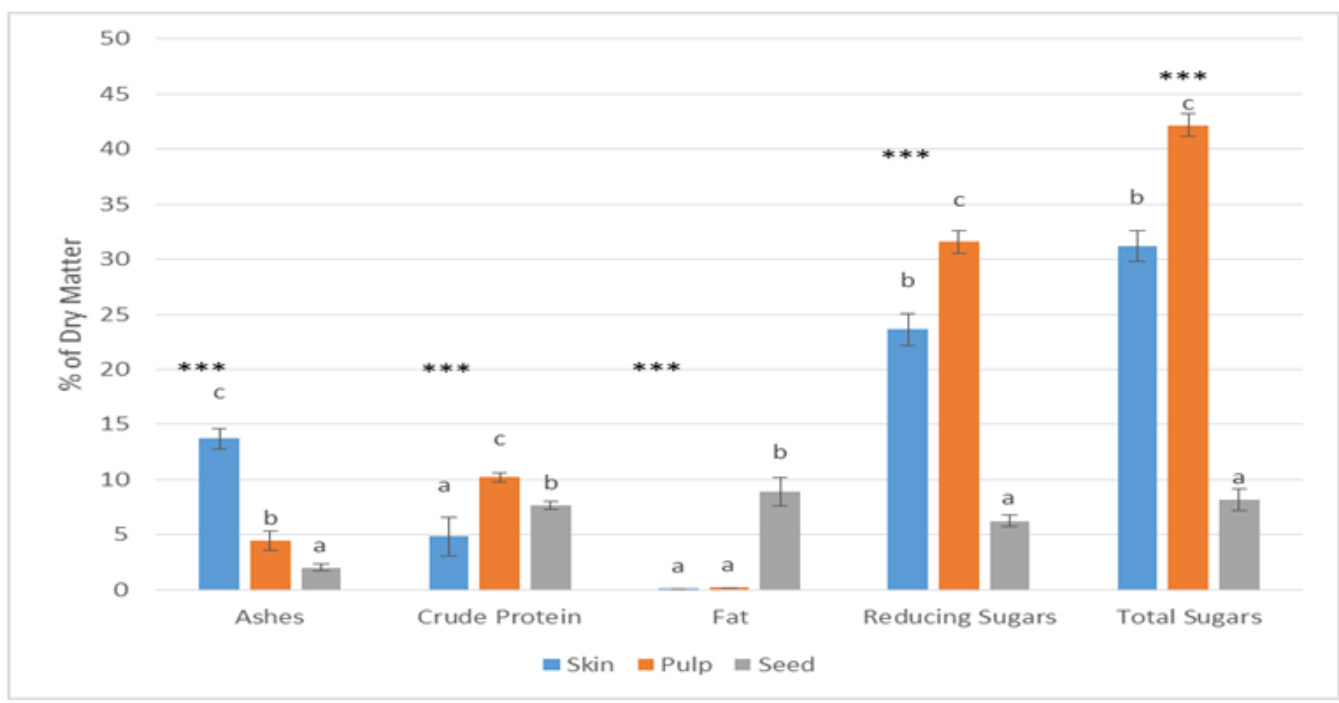

Fig 1:- Variation of ashes, crude protein, fat, reducing sugars and total sugars in different parts of the cactus fruit (The values represented by the columns with the same letter are not significantly different at the $5 \%$ threshold).

$* * *$ Very significant difference $\mathrm{p}<0.001$

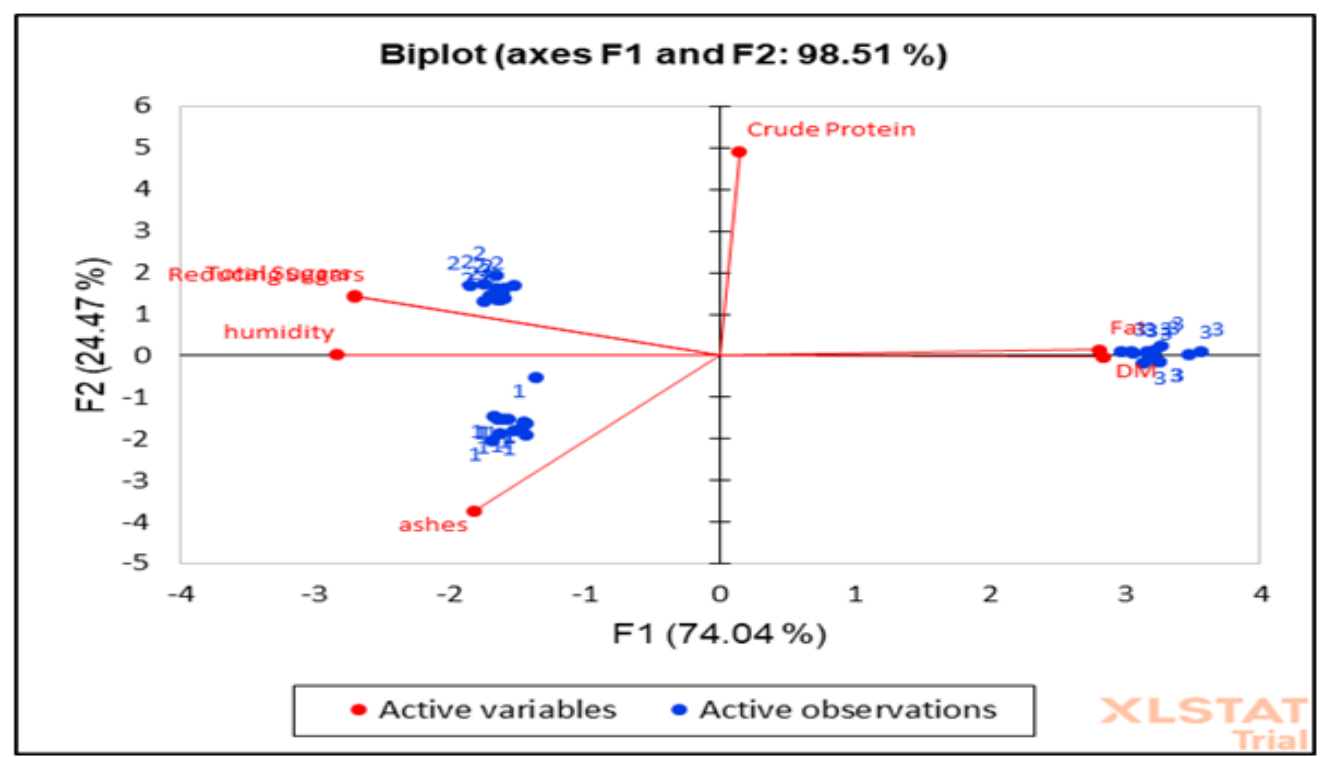

Fig. 2: Graphic representation of the three fruit fractions in Plan 1-2 of a principal component analysis based on biochemical determination (dry matter, moisture, reducing sugars, total sugars, mineral elements and fat).

With 1: peel, 2: pulp and 3: seed 


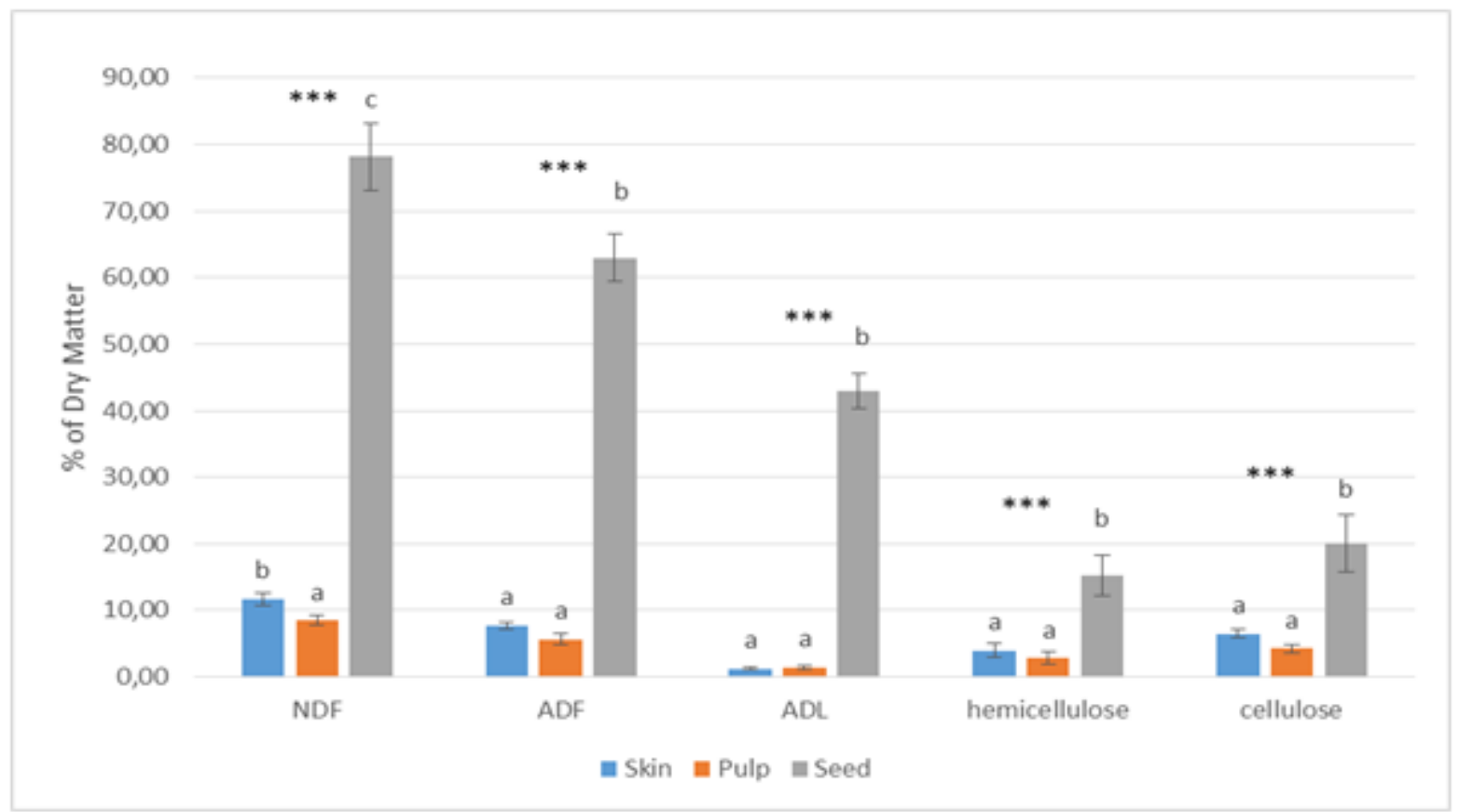

Fig. 3: variation of NDF, ADF, ADL, Cellulose and Hemicellulose in different parts of the cactus fruit (The values represented by the columns with the same letter are not significantly different at the $5 \%$ threshold).

$* * *$ Very significant difference $\mathrm{p}<0.05$

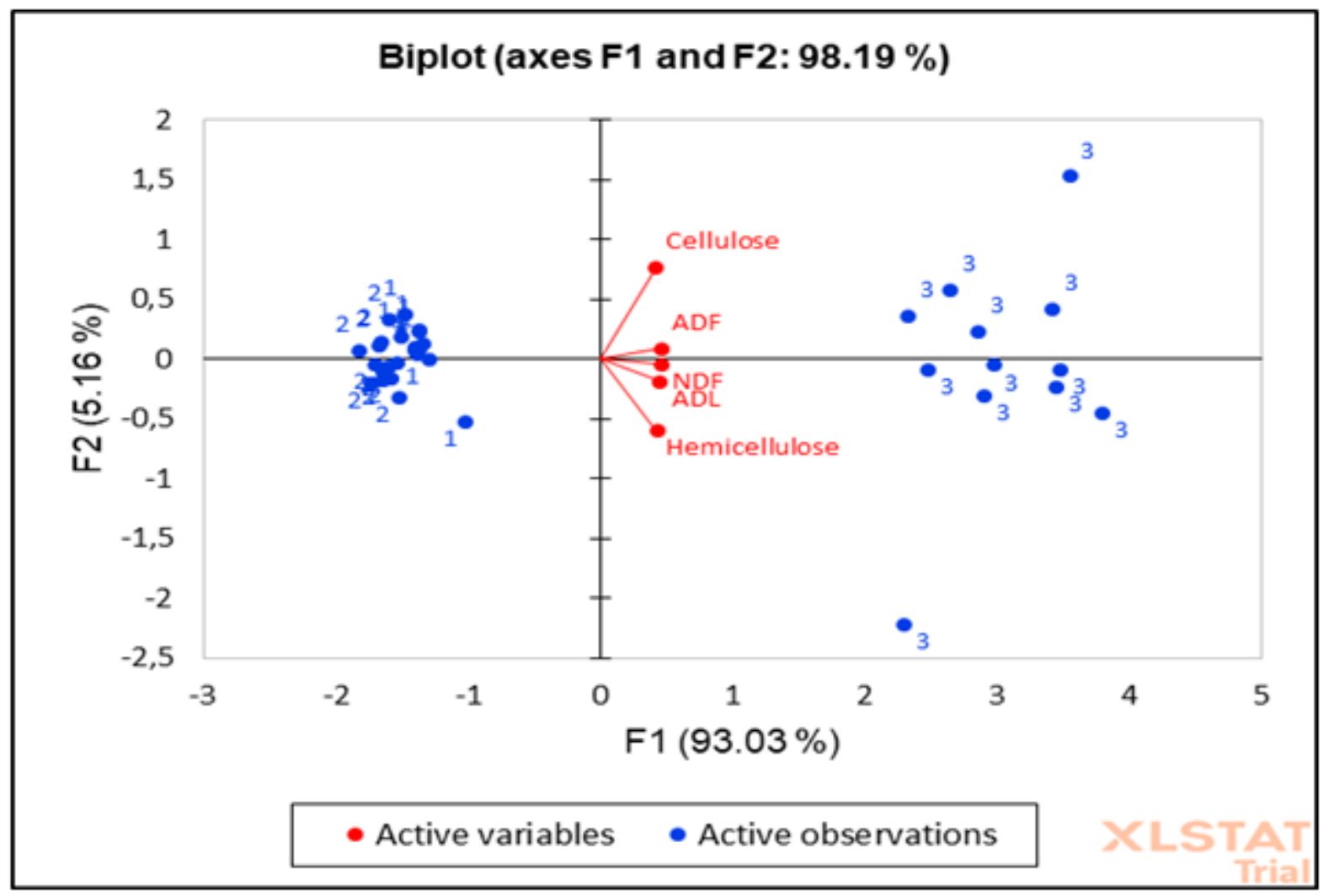

Fig. 4:- Graphic representation of the three fractions of the fruit in Plan 1-2 of a principal component analysis performed from the determination of fibers (NDF, ADF, ADL, hemicellulose and cellulose)

With 1: peel, 2: pulp and 3: seed 


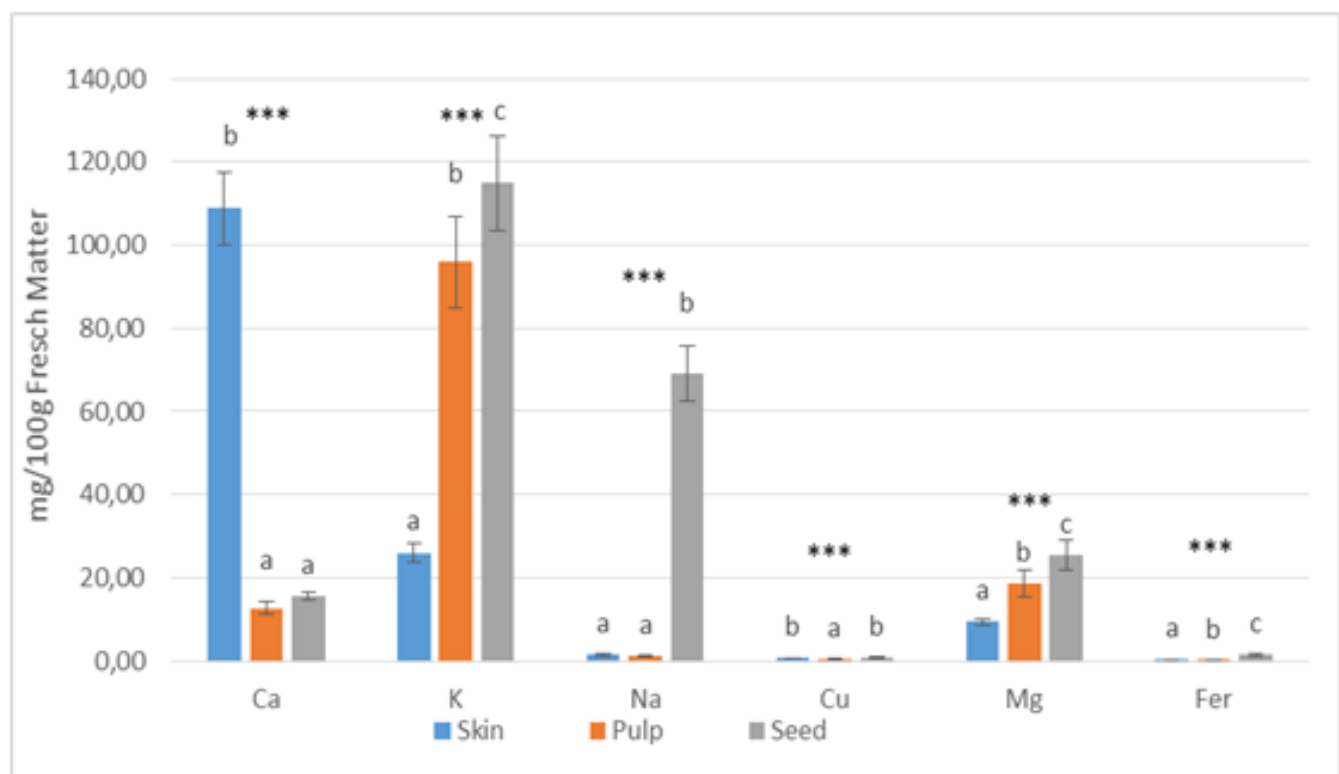

Fig. 5:- variation of mineral elements $\mathrm{Ca}, \mathrm{K}, \mathrm{Na}, \mathrm{Cu}, \mathrm{Mg}$ and fer in different parts of the cactus fruit (The values represented by the columns with the same letter are not significantly different at the $5 \%$ threshold). $* * *$ Very high difference $\mathrm{p}<0.05$

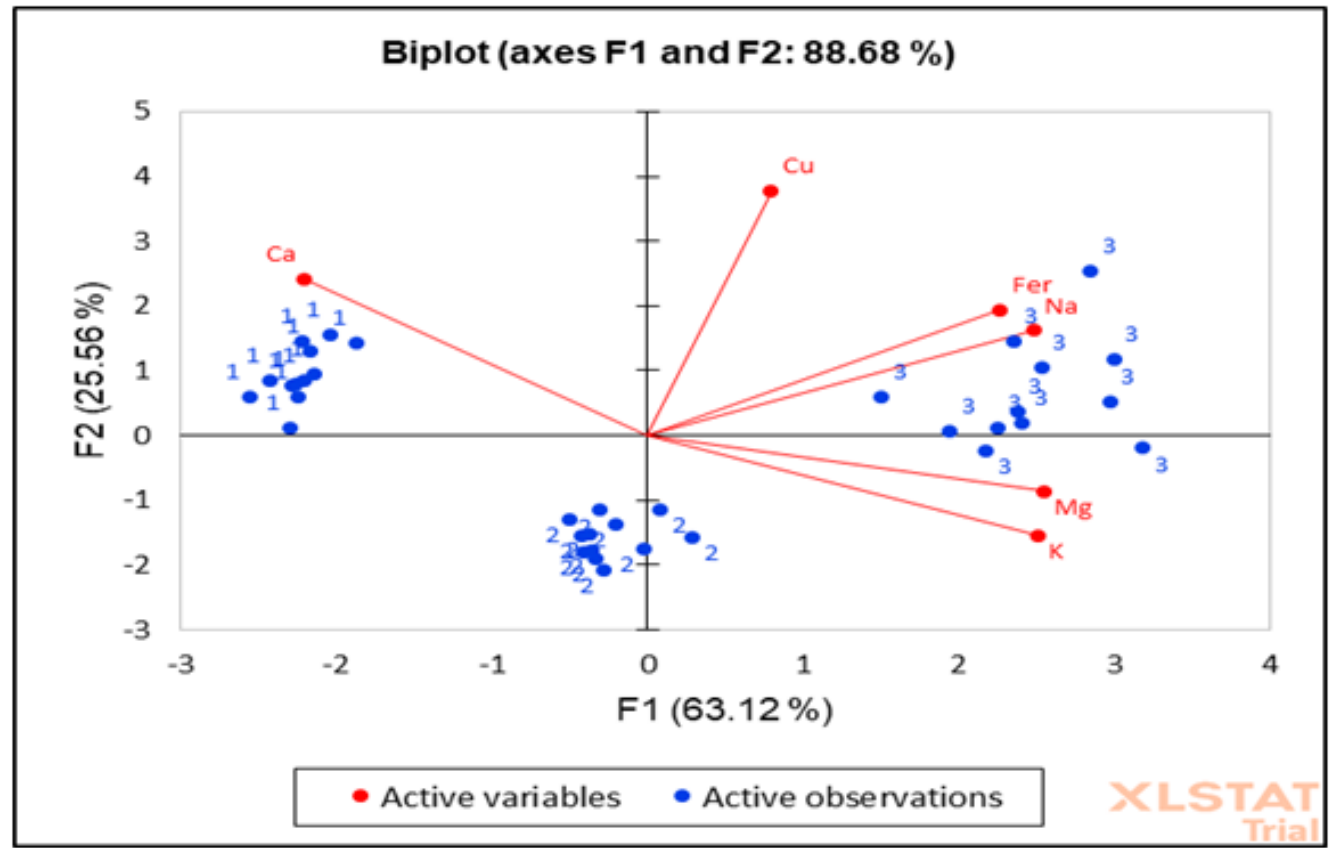

Fig. 6:- Graphic representation of the three fractions of the fruit in Plan 1-2 of a principal component analysis performed from the determination of mineral elements ( $\mathrm{Ca}, \mathrm{Cu}, \mathrm{K}, \mathrm{Mg}$, and Iron)

With 1: peel, 2: pulp and 3: seed

\section{CONCLUSION}

In the light of the results obtained, we can conclude that prickly pear skin have a low protein and fat content, a medium fiber content, high mineral elements (in order calcium, potassium and magnesium) and sugars content. The pulp is rich in sugars and mineral elements (in order potassium, calcium and magnesium), they have average fiber and protein content, a low fat content. As for seeds, they are rich in fat, fibers and mineral elements (in order potassium, sodium, magnesium and calcium,), they have average protein content and low in sugars.
Moreover, they are loaded in useful microorganisms (yeasts, lactic acid bacteria) and pathogenic ones (coliforms).

The composition of the three fractions (skin, pulp and seed) varies but remains complementary to use them in animal feed. This leads to the conclusion that it is a nonnegligible fraction that can be used as a source of fiber and mineral elements in animal feed. 
Unfortunately, cactus fruits have a short shelf life of 3 to 4 weeks, thus limiting its use in human consumption. But these fruits are still rich in energy and nutrients, this is why we propose through the results obtained, its use in animal feed after stabilization by fermentation.

\section{REFERENCES}

[1]. Ait Oubahou, and H. Bartali., "causes and importance of post-harvest losses of fruit and vegetables in Morocco," C. Locirignola, "land and sea: vital resources for the Mediterranean region," l'Harmattan, pp. 128-129, 2015 (in french).

[2]. Araba, M. Collado, A. Boutouba, A. Sahnoun, "novel feed for ruminants based on cactus fruit," PNTTA, technology transfer in agriculture, pp. 77-80, 2009 (in french).

[3]. Piga, "Cactus pear: a fruit of nutraceutical and functional importance," J. Profess. Assoc. Cactus. Dev, Vol. 6, pp. 9-22, 2004.

[4]. APHA, (Ameican Public Health Association), standard methods for examination of water and waste water (19th). Washington DC : APHA Pub lishers, 1134 P, 1989.

[5]. Matthäus, and M. Özcan, "Habitat effects on yield, fatty acid composition and tocopherol contents of prickly pear (Opuntia ficus-indica L.) seed oils," Sci. Hortic, Vol. 131, pp. 95-98, 2011.

[6]. E. Forni, M. Penci and A. Polesello, "A preliminary characterization of some pectins from quince fruit (cydonia oblonga mill) and prickly pear (Opuntia Ficus indica) peel," carbohydrate polymers, Great Britian, Vol. 23, pp. 231-234. 1994.

[7]. F.C. Stintzing, A. Schieber, and R. Carle, "Phytochemical and nutritional significance of cactus pear,” Eur. Food Res. Technol., Vol. 212, pp. 396407, 2001.

[8]. H. Ben Salem, A. Nefzaoui, and L. Ben Salem, "Spineless cactus (Opuntia ficus-indica f. inermis) and oldman saltbush (Atriplex nummularia L.) as alternative supplements for growing Barbarine lambs given straw-based diets,", Sma. Rumi. Res, Vol. 51, pp 65-73, 2004.

[9]. M. Bendaou, "process for obtaining a silage based on cactus and argan tree by-products," National agricultural research institute, WO MA 2013/105841 A1, 2013. (in french).

[10]. M. Chenost and C. Kayouli. Annex 6: "Average dietary value of major crop residues and agroindustrial by-products (according to INRA - 1988), Use of roughage in hot regions", FAO Study - Anim. Prod. Heal., Vol. 135, 1997.

[11]. M. Fadili, "Study of the physico-chemical characteristics of prickly pears of the Moussa and (Clone Rehamna) varieties". In 2nd national day on the culture of the cactus, El Kalaa Des SraghnaMorocco. 2000. (in french).

[12]. M. McConn, A. Michele, and P. Nakata, "Oxalate reduces calcium availability in the pads of the prickly pear cactus through formation of oxalate crystals," J.
Agric. Food Chem, 2004, Vol. 52, pp. 1371-1374, 2004.

[13]. N. Tlili, A. Bargougui, W. Elfalleh, A. Triki, and N. Nasri, "Phenolic compounds, protein, lipid content and fatty acids compositions of cactus seeds," J. Med. Plants Res., Vol. 5, pp. 4519-4524, 2011.

[14]. P.J. Van Soest, "Use of detergents in the analysis of fibrous feeds. II. A rapid method for the determination of fibre and lignin," J. Assoc. Off. Anal. Chem., Vol. 46, pp. 829-835, 1963.

[15]. R. El Kossori, C. Villanume, E. El Boustani, Y. Sauvaire, and L. Mejean, "Composition of pulp, skin and seeds of prickly pears fruit (Opuntia ficus-indica sp.),". Plant Foods Hum. Nutr, Vol. 52, pp. 263-270, 1998.

[16]. RNED, Canned fruit and vegetable and canning coproducts - fresh citrus pulp, ( INRA, 1988), National Network for Experimentation and Demonstration, France, National Committee of Co-products, file $\mathrm{n}^{\circ}$ 14, 2000. (in french).

[17]. SAS, SAS user's guide, SAS Institute, Inc. Cary, N.C. 1991.

[18]. T. Gebremariam, S. Melaku, and A. Yami, "Effect of different levels of cactus (Opuntia ficus-indica) inclusion on feed intake, digestibility and body weight gain in tef (Eragrostis tef) straw-based feeding of sheep," Anim. Feed Sci. Technol, Vol. 131, pp. 41-52, 2006.

[19]. Leininger, "Equipment, reagents, media, routine tests and strains," Compedium of methods for the microbial examination of foods, pp. 11-94. APHA, Washington, 1976

[20]. W.N. Sawaya, H.A. Khatchadourian, W.M. Safi, and H.M. Al Hammad, "Chemical characterization of prickly pear pulp, Opuntia ficus-indica, and the manufacturing of prickly pear jam," J. Food Technol., Vol. 18, pp. 183-193, 1983.

[21]. Y. Habibi, "Contribution to the morphological, ultra structural and chemical study of prickly pears," pp. 37, 2004. (in french). 